Int. J. Electrochem. Sci., 15 (2020) 2948 - 2960

\title{
Safe Hybrid Electrolytes Based on Ionic Liquid and Carbonate Solvents for High-Temperature Li-rich Lithium-Ion Battery
}

\author{
Liang Dong, Cuihua Li*, Fuxiao Liang, Jianhong Liu, Dong Wang, Dayong Gui, Caizhen Zhu \\ College of Chemistry and Environmental Engineering, Shenzhen University, Shenzhen 518060, China \\ *E-mail: licuihuasz@163.com (C. Li),2150110318@email.szu.edu.cn
}

doi: $10.20964 / 2020.04 .30$

Received: 5 May 2019 / Accepted: 1 July 2019 / Published: 10 March 2020

This work focuses attention on investigating N-butyl-N-methylpiperidinium bis(trifluoromethylsulfonyl) imide ( $\left.\mathrm{PiP}_{14} \mathrm{TFSI}\right) /$ carbonate-based electrolytes. The main goal is to substitute a conventional $\mathrm{LiPF}_{6} /$ carbonate electrolyte for $\mathrm{Li}$-rich/Li cells operating under both high voltage and high temperature. The safe electrolytes exhibit excellent physical and electrochemical properties at temperatures higher than $55^{\circ} \mathrm{C}$. The Li-rich/Li cells with ionic liquid (IL)/fluoroethylene carbonate (FEC)-based electrolyte obtained 163.1 and $180.3 \mathrm{~mA} \mathrm{~h} \mathrm{~g}^{-1}$ at $0.5 \mathrm{C}$ at $55^{\circ} \mathrm{C}$ and $1 \mathrm{C}^{\circ} 70^{\circ} \mathrm{C}$ after 100 cycles, respectively. The Li-rich/Li cell with IL/FEC-based electrolyte also achieved brilliant cyclic performance at $85^{\circ} \mathrm{C}$, which is considered an extreme temperature. The remarkable cyclic performance at high temperature is ascribed to a dense and robust solid electrolyte interface (SEI) film originating from the IL/FEC-based electrolyte. According to the properties of the IL/FEC-based electrolyte, the proposed electrolyte material is promising for application to a high-temperature lithiumion battery.

Keywords: High-temperature Li-rich cell; Safety; Ionic liquid; High voltage electrolytes; Solidelectrolyte interface

\section{FULL TEXT}

(C) 2020 The Authors. Published by ESG (www.electrochemsci.org). This article is an open access article distributed under the terms and conditions of the Creative Commons Attribution license (http://creativecommons.org/licenses/by/4.0/). 